\title{
Caduceus: A Medical Symbol of Deception, or Is There More to That?
}

\author{
George Katsaras, MD, MSc, PhDc1*; Vasiliki Chatziravdeli, MD MSc²; Dimitrios Katsaras, MD³; Garyfalia Papavasileiou, MD \\ 'Paediatric Department, General Hospital of Edessa, Edessa, Greece \\ ${ }^{2} 2$ nd Orthopaedic Department, General Hospital of Thessaloniki "Papageorgiou”, Thessaloniki, Greece \\ ${ }^{3}$ Lancashire Cardiac Centre, Blackpool Teaching Hospitals NHS Foundation Trust, Blackpool, UK \\ ${ }^{4}$ Eye Department, St James's University Hospital, The Leeds Teaching Hospital NHS Trust, Leeds, UK
}

\begin{abstract}
The serpent is the most popular representative symbol of medicine. The two main figures commonly used are the rod of Asclepius and the caduceus. Much controversy exists in the literature on whether the caduceus is a false symbol for medicine or not. The history of how these depictions came to be ambassadors of the medical science is elusive to many physicians. Scholars suggest that the origin of this false belief dates back to 1902, when the US Army Medical Corps first incorporated the caduceus as its symbol. This current essay is an attempt to discover and interpret how the snake came to be part of the rod of Asclepius and the caduceus, and constitute the symbol of medicine in our days. It is widely accepted that a doctor's obligation is not only in healing the ill, but the task that is bestowed upon him is more complex. Therefore, one should be considered more of a physician rather than simply a doctor.

Keywords: Caduceus, Medical symbol, Rod of Asclepius, Staff of Hermes

Cite this article as: Katsaras G, Chatziravdeli V, Katsaras D, Papavasileiou G. Caduceus: a medical symbol of deception, or is there more to that? Arch Iran Med. 2020;23(8):573-577. doi: 10.34172/aim.2020.65.
\end{abstract}

Received: February 11, 2020, Accepted: June 2, 2020, ePublished: August 1, 2020

\section{Introduction}

Throughout human history, the use of symbols has been a way to present powerful ideas, whose meaning was often lost or misinterpreted with the passing of time. ${ }^{1}$ The snake, which can be found in every culture, was used to symbolize emotions ranging from fear to adoration. ${ }^{2}$ The characteristic to shed its skin has been associated with the circle of life and the fact that the snake's own poison can also be the antivenom made it a metaphorical symbol for medicine. ${ }^{3}$ The two most renowned snake symbols used in medicine are the rod of Asclepius and the staff of Hermes or Caduceus. The rod of Asclepius is a staff entwined by a single snake, while the Caduceus is a short staff entwined by two serpents, sometimes surmounted by wings. ${ }^{4}$ Asclepius is the Greek God of medicine, while Hermes from the ancient Greek Pantheon, is the God of commerce, trade and merchants, as well as the protector of tricksters and thieves. Another less popular duty of Hermes was that of guiding the departed souls to Hades, the underworld of Greek mythology. ${ }^{5,6}$ One could suggest that the Rod of Asclepius is related to healing and life, while the staff of Hermes is related to death. A great conflict aroused in 1928 CE by Hattie W.H. on whether the Caduceus is a false symbol of medicine or not. ${ }^{7.8}$ The majority of scholars supported that the Caduceus was established in our era as the symbol of medicine due to a mistake that took place in
1902 CE, when the US Army Medical Corps started using it. ${ }^{9-11}$ The scope of this essay is to review the history of the snake and its symbolic use, and to interpret the meaning of the rod of Asclepius and the staff of Hermes using the information gathered through a "journey" in time.

\section{Ancient Mesopotamia}

In ancient Babylon, the single serpent depicted the great earth snake, the primal embodiment of the mother goddess, and the source of life. Consequently, the snake symbolized fertility and, with its return in spring, life and resurrection. ${ }^{12}$

The earliest type of Caduceus is found in ancient Babylonian cylinder seals. It constituted a sexual symbol with one male and one female head attached to a single body. ${ }^{13}$ It also appears on the libation vase of King Gudea (c. 2100 BCE), who ruled the Babylonian city of Lagash around 3000 BCE. The symbol comprised of two snakes entwined around a rod accompanied by two gryphons and represented Ningishzida, the "right-hand scepter god". Ningishzida was the "Herald of the Earth" and served as a liaison between the ruler and the mother goddess Ishtar, goddess of fertility, who was worshiped in Sumer as early as the Uruk period (4000-3100 BC) and held the Caduceus-Ningishzida in her hand. Similar representations of griffins and two coiled serpents sculpted 
on a marble amphora have been found in Jiroft, Iran, and date back to 2500 BCE. ${ }^{1,14}$ In the Epic of Gilgamesh (c. 1800 BCE), while reaching the end of his long journeys, Gilgamesh eventually possessed the secret to eternal life, a plant that could make someone young again. But shortly after taking hold of the plant, it was taken from him by a serpent while he was having a bath. Following this, the snake shed its skin and sneaked into the water. ${ }^{15,16}$ This is probably the first reference to the snake's attribute of losing their skin and the conviction that snakes could live forever. ${ }^{17}$

\section{Ancient Egypt}

In ancient Egypt, there is evidence of an existing relationship between the snake and healing. In a hymn, a workman in the Necropolis of Thebes reveals how the goddess Mertseger presented to him transformed as a serpent to remedy his disease and make his malady forgotten. Metrseger was a Theban cobra-goddess in ancient Egyptian religion (1550-1070 BCE) and is depicted as a mountain peak of the western desert. She was charged with guarding and protecting the vast Theban Necropolis and especially the Valley of the Kings. ${ }^{16,18-20}$

\section{Minoan Crete and Ancient Greece}

In c. 1600 BCE, the earth's ability to renew and revive herself was worshipped in the form of Diktynna, the Minoan "Great Goddess", who was represented with a serpent in each hand, emphasizing her domination over earth's blossom. ${ }^{1,2,10}$

What is more, the Cretan myth of Glaukos, son of Minos, correlates the snake with rebirth and resurrection. ${ }^{1}$ According to Hyginus, Glaukos, son of Minos, fell into a jar full of honey and died, while he was playing ball. Minos made inquiry to Apollo for the boy and then Apollo gave them an oracle telling them that the man that could explain the oracle would be able to restore Glaukos. Polyidus, son of Coeranus, was that man. Polyidus observed an owl putting bees to flight while sitting over the cellar. He interpreted the omen, and brought out the dead boy from the jar. Afterwards, Minos shut Polyidus with the dead boy in a tomb until Polyidus would bring the boy back to life. Suddenly, a snake approached the boy and Polyidus killed it as he thought it would devour the boy. Then, a second snake approached the first one, gave it an herb and life was restored to it. Polyidus did the same with Glaukos and the latter came back to life. ${ }^{21}$

\section{The Jewish Tradition}

In sacred texts of the Jewish tradition, the snake is depicted not only as a healer, but as a destroyer, as well. ${ }^{22}$ In the book of Genesis, the snake tempts Eve to eat the forbidden fruit from the Tree of Knowledge. As a consequence, the Lord God expelled Adam and Eve from the Garden of Eden. ${ }^{23-26}$
While traditionally, the snake is believed to be the Fallen Angel, according to another Hebrew legend, the snake is none other than the first bride of Adam, Lilith. Lilith is known as a demon stealing the infants of man for revenge because of a former curse that was bestowed upon her to daily suffer the loss of a hundred of her children. ${ }^{27}$

Although in the Book of Genesis the snake depicts cunningness and destruction, in the Book of Numbers, we can see the duality of the snake mentioned above. In c. $1400 \mathrm{BCE}$, the people of Israel were dying from a plague of "fiery" poisonous serpents sent by Jehovah, because they had spoken ill of him. Moses prayed to him and the Lord God asked him to make a serpent and put it around a pole. Anyone who had been bitten, if they looked at it (the brazen serpent, also known as Nehushtan), would be saved. And so it happened. The snake was simultaneously a destructor and a savior. ${ }^{2,6,17,22,26}$

\section{Hermes}

According to Frothingham, the ancestor of the Greek Hermes was the Babylonian Ningishzida. Hermes was a pre-Olympian God and the proto-Hermes was a snake God. He was a dual snake, incorporating both sexes, differentiating him from the Mother Goddess who was represented as the great single Earth Snake. This was the most fertile form of mating in the kingdom of animals. For this reason, the emblem of the God was the Caduceus (kerukeion in Greek, meaning "herald's wand"), a pair of snakes entwined around a wand or scepter. But before it became the god's emblem, the Caduceus had been, in the pre-anthropomorphic era, the God himself. ${ }^{12}$

According to the Homeric hymn to Hermes, Zeus's love affair with the nymph Maia resulted in the latter giving birth to Hermes in a cave. Shortly after leaving the cave, Hermes made the first seven-stringed lyre using sheep intestines, an ox's hide and reeds attached to a hollow turtle shell. Hermes was very cunning, and one day he stole the cattle of Apollo. ${ }^{28}$ Apollo, the father of Asclepius, warded off disease and healed the sick. ${ }^{7,29}$ When Apollo found out, he went to Zeus for a solution. Zeus ordered Hermes to show Apollo where the cattle were hidden. Following this, they reconciled. Hermes took hold of his lyre and captivated Apollo with his playing. Apollo then declared that Hermes would become the message-bearer of the Gods. Hermes gifted the lyre to Apollo, appointing him the master of the musical art, and Apollo in return gave Hermes a shining whip and made him the master of cattle herds. Moreover, following Hermes's oath not to steal again from Apollo, the latter gave to Hermes a golden staff, making him a guardian of wealth and prosperity. ${ }^{28}$ One day, Hermes came across two fighting snakes and, throwing his staff at them, they became intertwined and stopped fighting. Since then, Caduceus became his symbol. ${ }^{6}$ 


\section{Asclepius}

The first report of Asclepius is found in Homer's Iliad (1200-850 BCE). He was a king and had two sons, Machaon and Podaleirius, who were skilled physicians of the Greek army at Troy. ${ }^{29,30}$ Apart from these sons, he had also several daughters including Hygieia, Meditrina, and Panacea. ${ }^{1}$ The first reference about him being son of the God Apollo is the $16^{\text {th }}$ Homeric Hymn ( $8^{\text {th }}$ century BCE). ${ }^{31}$

After 420 BCE, Asclepius was raised to an Olympian God. In 293 BCE, a plague had corrupted Rome. The Roman sought advice from the Apollo's oracle at Delphi, where they were instructed to seek help from Asclepius at Epidaurus. The god, in the shape of a huge serpent embarked on the Roman ship, went to Rome and eradicated the plague. ${ }^{1}$ The shrine of Epidaurus was the first and most renowned of all the sacred places devoted to Asclepius. Many followed in more than 200 sites, amongst them Athens and Rome. The last one was at Tiber. ${ }^{17}$

Ovid, a Roman poet, in c. $8 \mathrm{CE}$ recounted the myth of Asclepius in his Metamorphoses. When Coronis was pregnant to Asclepius, she betrayed Apollo for the love of a mortal young man. Apollo found out and killed her with an arrow in her heart. Then, he ripped her dead body, took out Asclepius and entrusted him to the centaur Chiron. Chiron became Asclepius' mentor, teaching him the art and science of healing. Asclepius could even resurrect the dead, such as Hippolytes, Lycurgus, Capaneus and Glaukos the son of Minos. Pluto, the ruler God of Hades complained to Zeus about that and Zeus killed Asclepius with a thunderbolt. Apollo intervened and Zeus, realizing how important Asclepius was for mankind, resurrected him as an Olympian God. He placed him in the sky as the constellation Ophiuchus (the snake holder). ${ }^{32}$

Until now, we have commented on the relation of Asclepius to the snake. But what about the rod? According to some authors, early Greek physicians toured the countryside and carried instruments, medicines and a staff to help them over the rugged terrain. ${ }^{29}$ Antoniou et al gave another perspective of the symbolism of the rod. According to Pausanias, Daphne, daughter of Gaea, pleaded her mother to save her from Apollo's desire. Answering her call, she metamorphosed Daphne into a laurel tree. In honor of his lost love, Apollo made Daphne the oracle tree in Delphi. The authors suggested that the rod of Asclepius symbolizes this tree, the wisdom and the continuity of the medical knowledge. ${ }^{2}$

Many scholars have supported that the snake on the rod represents the method of extraction of the guinea worm (Dracunculus medinensis), that was used in ancient Greece, as well as in ancient Egypt according to the Ebers papyrus (c. 1550 BCE). To remove the worm from the victim's tissues, the healer winded it around a staff and slowly withdrew it with caution so that the worm was extracted in its entirety. $1,6,33,34$
The cult of Asclepius survived for 1000 years, from $5^{\text {th }}$ century BCE to $5^{\text {th }}$ century CE, until it was bitterly attacked as Christianity gained in popularity. ${ }^{35}$

\section{The Christian Tradition and the First Centuries Anno Domini}

In the New Testament, Jesus took the place of the brass serpent of the Old Testament, as healer of mankind's spiritual ills. ${ }^{36}$

Between the $6^{\text {th }}$ and $15^{\text {th }}$ centuries, the rod of Asclepius was substituted by the Cross and became a symbol of medicine with the snake twisted around it. ${ }^{2}$

As far as Caduceus is concerned, its first appearance as a medical symbol dates back to $1^{\text {st }}-4^{\text {th }}$ century CE in Oculists' stamps that were found mostly in Celtic areas, such as Gaul, Germany and Britain, which had an engraving of the name of the physician, the name of the special medicine or medical formula and the disease for which the medicine was to be used. ${ }^{13}$ The poison of the snake was considered panacea, and was used in the preparation of many medications. ${ }^{2}$

\section{Middle Ages and Renaissance}

The Caduceus gradually became the symbol of alchemy and pharmacy. This association dates back to the $2^{\text {nd }}$ century CE or even earlier, from reports found in the Hermetica texts, mentioning the great influence that the planet Mercury (Hermes) has on Earth. ${ }^{1,17}$ The Hermetica are Egyptian-Greek wisdom texts, which are mainly in the form of dialogues. A master, Hermes Trismegistus ("thricegreatest Hermes"), explains to a student. The texts pertain to the divine, the human intellect and natural environment. Some extend to subjects such as alchemy and astrology. ${ }^{17,37}$ Quicksilver (mercury) was named mercurius philosophorum by the alchemists, as it was believed to constitute the basis of all substances. ${ }^{17} \mathrm{~A}$ medieval alchemist or a student of the history of chemistry would suggest that the Caduceus was used because the various preparations of Caius Silvius Tetricus contained quicksilver or mercury. This element has been represented by the caduceus for many centuries. ${ }^{13}$

Mercury/Hermes prevailed in alchemy and by the 16th century, the Caduceus had turned into a symbol of medicine and drugs. ${ }^{17}$ On a picture of the alchemist Salomon Trismosin dated in the $16^{\text {th }}$ century, an old king in a closed flask is being purified under the quote "Filius natus ex me, maior est me" ("Son born by me, greater than me"), while Hermes is riding the clouds in a chariot holding the Caduceus in his hand. Despite the fact that the majority of authors during Renaissance correlated Caduceus with medicine, Caduceus has an important symbolic meaning. The course of the soul through unknown trails to be redeemed is parallelized with the disease, and Hermes and his staff are redemptory symbols of the sick. ${ }^{2}$

The Caduceus was used as a symbol related to medicine by two printers who conducted some medical printing, 
Erhard Ratdolt in 1486 CE and Johann Froben in 1518 CE. Sir William Butts, a physician, adopted it as his emblem.

The rod of Asclepius, since the 5th century CE, resurfaced in $1544 \mathrm{CE}$. A publication of the medical writings of Avicenna, a Persian physician, had it at the frontispiece. ${ }^{14}$

\section{The Modern Era}

In 1792 CE Josiah Flagg Jr., a surgeon dentist, used Caduceus in an advertisement in the Boston Columbian Sentinel. ${ }^{14}$ It reappeared in medical books by John Churchill in the 19th century CE. ${ }^{1,10,11,17,38}$ He probably did not use it as a medical symbol, but more as an attempt to put together medicine and literature, since it comprised of two snakes named "medicina" and "literis" and a quote "Irrupta Tenet Copula" (unbreakable bond unites). This is further reinforced by the fact that he used Asclepius in some of his books, as well. ${ }^{10}$

The rod of Asclepius appeared in the coat of arms of the Medical Department of the US Army in 1818 CE and the American Medical Association in 1910 CE, while the caduceus appeared in the US Army Medical Corps in 1856 CE and the US Air Medical Corps in 1902 CE. ${ }^{6,9,11,14}$ After that, a lot of medical organizations followed. Due to a "dispute" that erupted in the late 20 th century CE, many medical organizations changed their logo and at the time, up to $62 \%$ of them were using the rod of Asclepius as their symbol. $^{2}$

\section{Discussion}

Our journey in history revealed that the single snake was primarily the symbol of mother earth, the source of life. ${ }^{12}$ In ancient Egypt, it depicted wisdom as well as life. ${ }^{14}$ In the Minoan Crete and Mesopotamia, it symbolized fertility, while its first reference as a symbol of destruction is found in the the Fall of Adam and Eve, in the Book of Genesis. ${ }^{2,12,24}$ Its relation to rebirth and resurrection is found in the myth of Glaukos, son of Minos, and its potential to be a savior from death in the Brazen Serpent of Moses. ${ }^{21,26}$ The latter ability remained, and was depicted in the face of Jesus. ${ }^{36}$ As far as its relation to healing is concerned, we found references in the Egyptian goddess Mertseger, the Cretan goddess Eileithyia and the ancient Greek God of medicine Asclepius. ${ }^{1,2,16,32}$

The rod with the entwined snake is found only as the symbol of Asclepius and from a point of view, it could originate from the treatment of the guinea worm in ancient Greece and Egypt. ${ }^{6,33,34}$ The art and science of medicine, that were practiced in Asclepiea, correlated more to magic than medicine as we know it today. In the early years, Asclepius visited the sick in their dreams in the form of a serpent. Later on, the Asclepiads used their patients' dreams, to follow specific procedures for diagnosis and treatment, such as lifestyle changes and massage. ${ }^{2,17}$ This emblem in the early Christian Era was replaced by a cross with an entwined snake, but it reappeared in 1544 CE. ${ }^{2,14}$

The Caduceus dates back to ancient Babylon, symbolizing Ningishzida, the "Herald of the Earth", while we find him in other sources depicted by a staff and only one snake. ${ }^{1,16}$ According to some authors, Ningishzida continued to the ancient Greek God Hermes, who among other things, was the guide for the departed souls to Hades. ${ }^{5,6}$ In the first centuries CE, Caduceus is found in Oculists' stamps and, from the beginning of the Middle Ages, alchemists started using it. By the 16th century, the Caduceus had turned into a symbol of medicine and drugs. ${ }^{13,17}$ By most authors, if not all of them, the Caduceus is a false symbol for medicine. ${ }^{1,2,4-11,13,14,16,17,22,29,34,35,38}$

Medicine is the science and practice of the diagnosis, treatment, prognosis and prevention of disease. The word "medicine" is derived from Latin medicus, meaning "a physician". ${ }^{39,40}$ If we consider the physician to be only a healer, then the rod of Asclepius is indeed the proper symbol for medicine. Nevertheless, there are conditions that need skilled symptom management, communication, and spiritual support. No proper treatment exists and the physician is called to deliver palliative care in order to provide some comfort in the last days of a patient's life. In these situations, where a disease cannot be cured, but a patient-centered care is mandatory for the alleviation of physical and spiritual pain, the physician is more like Hermes than Asclepius. ${ }^{41}$ Just as Hermes guides the departed souls to Hades, the physician tries to make this transfer as smooth as possible. We do not know if those who supposedly by mistake used Caduceus as a medical symbol had thought of this metaphor, but it is well accepted that a physician cannot always cure. He can, though, provide the best he can to alleviate his patients' symptoms and pain.

\section{Authors' Contribution}

GK participated in conceptualization, investigation, methodology, writing and original drafting the manuscript. VC was responsible for investigation, methodology, validation, editing and reviewing the paper. DK and GP participated in supervision, editing, reviewing and validating the final form.

\section{Conflict of Interest Disclosures}

All authors declare that they have no conflict of interest.

\section{Ethical Statement}

Not applicable.

\section{References}

1. Nayernouri T. Asclepius, Caduceus, and Simurgh as medical symbols, part I. Arch Iran Med. 2010;13(1):61-8.

2. Antoniou SA, Antoniou GA, Learney R, Granderath FA, Antoniou Al. The Rod and the Serpent: History's Ultimate Healing Symbol. World J Surg. 2011;35(1):217-21. doi: 10.1007/s00268-010-0686-y.

3. Ramoutsaki IA, Haniotakis S, Tsatsakis AM. The snake as the symbol of medicine, toxicology and toxinology. Vet Hum Toxicol. 2000;42(5):306-8.

4. Larose C. The caduceus v. the staff of Aesculapius. Can Med Assoc J. 1979;121(2):158.

5. Shetty A, Shetty S, Dsouza O. Medical Symbols in Practice: 
Myths vs Reality. J Clin Diagn Res. 2014;8(8):PC12-PC14. doi: 10.7860/JCDR/2014/10029.4730.

6. Prakash M, Johnny JC. Things you don't learn in medical school: Caduceus. J Pharm Bioallied Sci. 2015;7(Suppl 1):S49-S50. doi: 10.4103/0975-7406.155794.

7. Hattie WH. The Caduceus. Can Med Assoc J. 1928;18(1):7980.

8. Fromson JA. The Asclepius: the ancient standard of physicians. Am J Psychiatry. 2011;168(7):752. doi: 10.1176/appi. ajp.2011.11040539

9. Hunt D. Medical school logos: how many snakes? Acad Med. 2012;87(10):1313-4. doi: 10.1097/ACM.0b013e31826744a0

10. Wilcox RA, Whitham EM. The symbol of modern medicine: why one snake is more than two. Ann Intern Med. 2003 Apr 15;138(8):673-7. doi: 10.7326/0003-4819-138-8200304150-00016.

11. Sacks AC, Michels R. Images and Asclepius. Caduceus and Asclepius: history of an error. Am J Psychiatry. 2012;169(5):464. doi: 10.1176/appi.ajp.2012.11121800.

12. Frothingham AL. Babylonian Origin of Hermes the SnakeGod, and of the Caduceus I. Am J Archaeol. 1916;20(2):175211.

13. Hart GD. The earliest medical use of the caduceus. Can Med Assoc J. 1972;107(11):1107-10.

14. Metzer WS. The caduceus and the aesculapian staff: ancient eastern origins, evolution, and western parallels. South Med J. 1989;82(6):743-748. doi: 10.1097/00007611-19890600000017.

15. Sanders NK. The Return. In: The Epic Of Gilgamesh. Assyrian International News Agency. Books online: 22-3. Available from: http://www.aina.org/books/eog/eog.pdf. Accessed 2019 Oct 29.

16. Bunn JT. Origin of the caduceus motif. JAMA. 1967;202(7):615619.

17. Retief FP, Cilliers L. Snake and staff symbolism, and healing. S Afr Med J. 2002;92(7):553-6.

18. Lichtheim M. Ancient Egyptian Literature. Volume II: The New Kingdom. Los Angeles: University of California Press; 1976:107-9.

19. Pinch G. Handbook of Egyptian Mythology. USA: ABC-CLIO, Inc; 2002:214-6.

20. Hart G. A Dictionary of Egyptian Gods and Goddesses. 2nd ed. London: Routledge; 2005:91-2.

21. Hyginus GJ. The Myths of Hyginus. Translated by: Grant M, 1st ed. USA: University of Kansas Publications; 1960:244.

22. Jones KB. The staff of Asclepius: a new perspective on the symbol of medicine. WMJ. 2008;107(3):115-116.

23. Genesis 3. The Fall 1-24. In: Holy Bible New International Version. Available from: https://www.biblegateway.com/ passage/?search=Genesis+3\&version=NIV. Accessed 2019 Oct 29.

24. Genesis 3. The Fall 1-5. In: Holy Bible New International
Version. Available from: https://www.biblegateway.com/ passage/?search=Genesis+3\&version=NIV. Accessed 2019 Oct 29.

25. Genesis 3. The Fall 22-23. In: Holy Bible New International Version. Available from: https://www.biblegateway.com/ passage/?search=Genesis+3\&version=NIV. Accessed 2019 Oct 29.

26. Numbers 21. The Bronze Snake 4-9. In: Holy Bible New International Version. Available from: https://www. biblegateway.com/passage/?search=Numbers $+21 \% 3 \mathrm{~A} 4$ 9\&version=NIV. Accessed 2019 Oct 29.

27. Wolkstein D, Kramer SN. Inanna: Queen of Heaven and Earth: Her Stories and Hymns from Sumer. New York: Harper \& Row Publishers; 1983.

28. Morford POM, Lenardon JR, Hermes SM. Classical Mythology. 9th ed. United Kingdom: Oxford University Press; 2011.

29. Hart GD. Asclepius, God of Medicine. Can Med Assoc J. 1965;92:232-6.

30. Homer. Book 2. 729-733. In: Iliad. Available from: http:// www.perseus.tufts.edu/hopper/text?doc=Perseus\%3Atext\%3A1999.01.0134\%3Abook\%3D2\%3Acard\%3D695. Accessed 2019 Oct 29.

31. Homer. Hymn XVI (To Asclepius). In: Hesiod, the Homeric Hymns and Homerica. Translated by Evelyn-White HG. 1st ed. New Haven: Harvard University Press; 1920:440.

32. Ovid. Metamorphoses Translated by Sir Samuel Garth, John Dryden, Alexander Pope, Joseph Addison, William Congreve. CreateSpace Independent Publishing Platform; 2016.

33. Miller RL. Dqr, Spinning and Treatment of Guinea Worm in P. Ebers 875. J Egypt Archaeol. 1989;75(1):249-54.

34. Crocker MC. The staff and the "fiery serpent". CMAJ. $2002 ; 166(4): 425$.

35. Frey EF. The caduceus and the staff of Aesculapius from antiquity to the present. Tex Rep Biol Med. 1978;36:1-15.

36. John 3. 14-15. In: Holy Bible New International Version. Available from: URL: https://www.biblegateway.com/ passage/?search=John+3\%3A14-15\&version=NIV. Accessed 2019 Oct 29.

37. Copenhaver BP. Hermetica: The Greek Corpus Hermeticum and the Latin Asclepius in a New English Translation, with Notes and Introduction. Cambridge University Press; 1995.

38. Coston TO. The proper symbol of medicine. Trans Am Ophthalmol Soc. 1970;68:359-63.

39. Lexico.com: Medicine. Available from: https://www.lexico. com/en/definition/medicine. Accessed 2019 Oct 29.

40. Online Etymology Dictionary: medicine (n). Available from: https://www.etymonline.com/word/medicine. Accessed 2019 Oct 29.

41. Ernecoff NC, Wessell KL, Hanson LC, Dusetzina SB, Shea CM, Weinberger $M$, et al. Elements of Palliative Care in the Last 6 Months of Life: Frequency, Predictors, and Timing. J Gen Intern Med. 2020;35(3):753-61. doi: 10.1007/s11606-019-05349-0. 